\title{
Technology giants, educational policy and a preliminary mapping of networks and channels of influence in a Norwegian context
}

\author{
Geir Haugsbakk \\ Innland Norway University of Applied Sciences \\ Geir.Haugsbakk@inn.no
}

\section{Abstract}

The article looks at the debate regarding the influence of the technology giants on educational policy. What strategies have existed on the part of the technology giants? Who have been the major actors within education? What kind of relations and networks have been established? The first part of the article focuses on relevant research internationally showing that the technology giants have taken the lead and that their objectives are to develop new long-term policy agendas. The development has been significantly intensified and to some extent changed during the pandemic. This has resulted in the emergence of new multisector coalitions and more complex networks which have potentially profound pedagogical implications. The second part accounts for a preliminary mapping of networks and channels of influence in a Norwegian context. Despite the differences between countries, political and educational systems, traditions and values, there are a number of the similarities in the field of educational technology. These include on a general level how the use of new technology is valued as a way of improving teaching and learning, but also how networks and relations are developed and function. The project that precedes the article is based on literature studies and inspired by network ethnographic approaches.

Keywords: technology giants, educational policy, channels of influence, Norwegian context 


\section{Introduction}

Classrooms are being filled up with tablets, computers and associated apps and software from global technology companies. The school market has proved to be highly profitable, and the technology companies have for the last three decades attempted to influence educational policy (Picciano \& Spring, 2013). The pressure intensified through out 2020 due to the pandemic and school closures (Williamson \& Hogan, 2020). The situation is challenging as the technology giants are now the world's largest companies by market capitalization and are getting bigger (Global Finance, 2020), and they are making huge profits running global businesses beyond national control. Digital media and technology, which are at the heart of the global economy, have been referred to as digital capitalism "catalyzing an epochal political-economic transition" (Schiller, 1999). In recent years, this has been characterized as surveillance capitalism (Zuboff, 2019) based on the assumption that human experience is the raw material and the fact that the leading actors know "everything” about us.

Throughout 2020 the edtech industry, more so than was previously the case, has delivered the promise of personalised learning as an appropriate response to the current situation, but also as a vision of education in the 21st century (Colclough, 2020). Thus their objectives are not just to be regarded in the short term. They are developing new long-term policy agendas for how education systems globally should be organized after the pandemic (Williamson, 2020). This might partly be regarded as a new kind development, but may also be seen as a prolongation of a development over the last 30 years.

The above-adumbrated situation provides the starting point and framework for examining the channels of influence. What strategies have existed on the part of the technology giants? Who have been the major actors within education? What kind of relations and networks have been established? The first part of the article focuses on relevant research internationally. This part also provides the academic and theoretical framework for the article. The second part goes on to offer accounts for a preliminary mapping of networks and channels of influence in a Norwegian context.

\section{Methodological considerations}

The first part of this project is to a large extent based on literature studies. Several interesting contributions have been made in international research regarding the largest technology companies and their influence. The major edtech companies, the networks surrounding them, how they have collaborated or competed and their potential influence on educational policy, have received less attention in Norway and have not been analysed systematically. Therefore, the mapping of actors and their relations and influence which form the basis of this article, is somewhat preliminary in character. The main approach in this regard has been to search for websites containing key information and media 
coverage, but also consulting magazines, journals and newspapers and following debates in various media.

There are many challenges when it comes to obtaining relevant information on these issues. Information available on the activities in question is often limited. Many of the activities are undocumented and based on informal contacts. Some relevant information have been disseminated via websites that have been updated later on or removed for various reasons. Moreover, web pages may have been removed due to reorganizations. Several websites are through the article referred to in footnotes. These are used as examples to illustrate the patterns of activities by actors and networks detected thorugh the analysis. As most of the current websites have Norwegian language, the texts used in the article are translated by the author.

At the start of his work mapping out the actors who have emerged as influential through the pandemic in connection with educational technology, Williamson (2020) underlined the need for "a descriptive, first-draft sketch" of current policy developments. Then much more sustained analytical work remains to be done. That's also the case for the analysis of the situation in Norway. It constitutes a first step trying to get an overview and to detect some main patterns of activities. However, a lot more systematic work is needed.

The analysis of the Norwegian actors in the field of educational technology has been inspired by network analysis, a kind of network ethnography, which goes into the flexible networks replacing the hierarchical structures of the past and opening up for new actors. These networks include a variety of relationships and rather "complicated issues of purpose, ownership and control” (Ball \& Junemann, 2012, p. 36). On a broad basis, network ethnography might include internet searches, interviews and the construction of network diagrams (Hogan, Sellar \& Lingard, 2016a). The project presented in this article is thus based on a limited approach. It does not include interviews, and the diagrams have been replaced by more general presentations of actors and networks.

The analyses also take their cue from discourse analytic approaches. These concern the way meaning is created through language aiming at revealing patterns of meaning-making (Wetherell et al., 2001). They are about the importance of key concepts to perceive the world (Koselleck, 2004), and how they connect to ideas and arguments and form discourses searching for hegemony (Laclau \& Mouffe, 2001).

\section{Contradictory, complex and changing discursive constructions}

The mapping of actors, activities, relationships and influence in the field of educational technology is not a straightforward task. The perception of the field, the technology and its leading actors can be seen as a discursive construction characterized by contradictions, 
complexity and changes.

The field is inherently contradictory inasmuch as educational technology has always been a mix of rather naive optimism and critical voices. The representatives of the big technology companies were for a long time mainly regarded as "the good guys, helping everyone optimize digital opportunities" (Andriole, 2019). There has always been some criticism, but as a consequence of the scandal of Cambridge Analytica the technology giants have by many been put on the list of "the most disrespected companies!" (Andriole, 2019). Claims have been made in academic literature that "big business is taking over public schools" (Hogan, 2015a), and that "public-private partnerships" are primarily business oriented (Hogan, 2015b). However, the optimism in the field and the strong position of the tech companies to a small extent have been challenged.

An important part of this development is the great and increasing complexity and the rapid changes going on all the time, making it difficult for everyone involved, including researchers. Through globalization intergovernmental relationships are being replaced by less visible interactions between non-state actors (Picciano \& Spring, 2013). The same goes for the privatization of government services and the increasingly large group of actors leaning on the technology providers and sharing a "pro-technology-agenda" (Selwyn, 2011).

\section{A prolongation of developments from the 1990s onwards}

The growth of the edtech industry accelerated during 2020 and the actors, their networks and attempts to influence educational policies worldwide have become increasingly more visible. However, the early stages of the developments can be seen from the 1990 on onwards through the establishment of the "great American education-industrial complex" (Picciano \& Spring, 2013) and the emergence of the global education industry (Verger, Lubienski \& Steiner-Khamsi, 2016).

In 1994 Picciano described what he defined as the beginning of an "educational-industrial complex". For Picciano, the reason was obvious: Selling technology to schools had become "big business", and he identified close relations between business, politics and large and growing networks with common interests related to technology in education (Picciano, 1994). A fully developed educational-industrial complex has gradually been developed. This complex comprises networks of government agencies, foundations, venture philanthropies, think tanks, media companies, and education technology providers who seek to promote their own beliefs, products and services. They have reached a position which enables them to influence policy making (Picciano \& Spring, 2013, p. 2).

The Gates foundation is presented as one of the key actors investing billions of dollars in 
school "reform" initiatives, funding large research projects, and being a part of a network of foundations, ICT companies and government agencies" (p. 31). The important roles of the so-called "flexians" are underlined, persons moving back and forth between the big companies and the U.S. Department of Education. They are creating new forms of governance where decisions are made and discussions take place outside of established government channels.

The development described regarding educational technology corresponds to a large extent with notions of the rise of the global education industry (Verger et al., 2016). This industry is based on the idea of education "as a sector for investment and profit making, where organizations, practices and networks engaged in these endeavors take on an increasingly global scale" (p. 3). The world's largest edu-business, Pearson pl., was quick to recognise the potential value of this market of education as "the biggest growth industry of the 21st century" (Pearson plc, 2012, p. 8). Pearson has also been highly influential with policy makers and politicians, and international organizations have embraced the company's presence. This is also the case for OECD which made Pearson a partner in developing the PISA tests (Hogan, Sellar \& Lingard, 2016b, p. 107).

The companies at the forefront have taken advantage of the uncertainty surrounding the "new" world. The unique characteristics of today's society have been almost invisible to most of us. When we encounter something "unprecedented", we automatically interpret it through the lens of familiar categories, like the notion of the "horseless carriage" confronted with the automobile. The unique characteristics are obscured by turning the unprecedented into an extension of the past. This is how Shoshana Zuboff (2019) explains the challenges in seeing through surveillance capitalism, the invention by Google that quickly spread to Facebook (p. 12).

\section{A pandemic shock - extended and more powerful networks}

The attention given to the networks in the field of educational technology has been increasing in the research literature over the last decade, and the potential consequences have been put at the forefront. The main actors in the edtech industry and their partners of highly different kinds are presented as "complex, entangled interrelationships that have affected the content and delivery of education at all levels" (Regan \& Khwaja, 2019). One of the points to emerge is how education is "increasingly targeted by intermediary organizations representing particular kinds of agendas and are able to translate interests across the commercial, civil society and governmental sectors projects" (Williamson, 2016).

In 2020 some of the key actors significantly intensified their efforts, privatisation and commercialisation of education increased and new networks, coalitions and alliances were 
established. Williamson and Hogan (2020) have concluded that the 2020 pandemic led to a "huge effort to create multisector coalitions, public-private partnerships and networks in which commercial actors play a key part, and we have seen the development of a range of interdependencies between various organisational types" (p. 66). Perrotta (2020) highlights how digital infrastructures are coming together in higher education as "a nuanced socio-technical process involving multiple actors and influences: technological tools and frameworks, gifted 'nerdy' developers, 'caring' educational researchers, managers/administrators, corporate interests and so forth".

This tendency is illustrated by the partnership between New York state represented by governor Andrew Cuomo and the Bill and Melinda Gates Foundation agreeing on an ambition to create "a smarter education system" making a lot of buildings and classrooms redundant (Klein, 2020). Concern has been expressed that a post-pandemic future might entail partnerships between the largest technology companies and the elite universities allowing universities "to expand enrollment dramatically by offering hybrid online-offline degrees" (Walsh, 2020).

Large international organisations have been actively involved as important parts of new coalitions and collaborative initiatives. These include UNESCO, UNICEF, The World Bank and OECD. In a press release issued in March 2020 UNESCO announced that a whole range of partners had joined their global education coalition to scale up distance learning practices in order to deal with the challenge of the world's student population which was affected by COVID-19 school closures. Multilateral partners were presented such as the International Labour Organization, UNICEF, the World Health Organization, the World Bank, the World Food Programme and the International Telecommunication Union and OECD. Private companies like Microsoft, Google and Facebook were made partners (UNESCO, 2020). In April 2020 UNICEF and Microsoft announced that they had launched "a global learning platform to help address COVID-19 education crisis" (UNICEF, 2020). The UNICEF Executive Director declared that along with "long-term partners like Microsoft", they were able to "swiftly deploy innovative, scalable solutions for children and youth".

The World Bank has been actively working with ministries of education in several countries with a view to developing remote learning opportunities. The OECD has characterised the huge edtech response during the pandemic as "a great moment", adding that real change happens during crisis. The result is that the big technology companies have been intervening education systems in ways that suggest "new forms of power and influence over education and its future" as they offer easily accessible technological solutions to solve complex policy problems (Williamson, 2020). 


\section{Educational influence and pedagogical implications}

The new coalitions involving the large technology companies might make sense in the short term and on grounds of efficiency, according to Williamson and Hogan (2020), but the shift in authority from the state to private actors is challenging as far as democratic control and professional autonomy are concerned. The position of teachers is reduced. Based on a survey, Education International, the world's largest federation of unions across the globe, concludes that there is also a lack of union consultation by education authorities with regards to the introduction of new digital technologies (Colclough, 2020, p. 56).

Knox, Williamson \& Bayne (2020) introduce the concept "machine behaviourism" to characterise personalised learning where behaviours and actions are increasingly understood to be both "machine-readable by learning algorithms and modifiable by digital hypernudge platforms". The learner is now seen as a "rational and emotional subject", and this marks a "(re)turn to the influence of behaviourist psychology on educational practice, and appears to usher in new powerful regimes of centralised control" (Knox, Williamson \& Bayne, 2020). This is clearly opposed to Gert Biesta's perception of "learnification" and the new language of learning that entails a market-driven educational system where the learners' perspectives and constructivist pedagogies were placed at the centre (Biesta, 2004).

Perrotta, Gulson, Williamson \& Witzenberger (2021) have examined Google Classroom as an exemplar of platformized infrastructure representing a specific form of pedagogic participation. They conclude their analyses of platform pedagogy by referring to the concept of a "doubly articulated pedagogy". The first articulation is "the off-loading of aspects of educational practice onto apps and other platforms". This implies the fragmentation and automation of participation shaped by the infrastructure offered by Google, and the possible exclusion of educators. The second articulation is "the algorithmic learning from data" where "the learning flows from the users to the platform, which continuously gazes back upon them".

The pedagogical implications could be far-reaching. Such analyses have also provided a basis for reflections on a new critical media education. According to Selwyn (2020) it is important "to push the counternarrative that the re-imagining of public education is not a tech issue". The conversations should be directed towards "the heart of the matter - i.e. education as a social concern". He goes on to add that inspiration might be drawn from reasoning and sense-making by critical education scholars over the past 30 years.

An important part of this new development is the need to address changes taking place in contemporary childhood. Young people are particularly vulnerable as far as personal data collection is concerned, and they need help "to understand the realities of living in a datafied society" (Pangrazio \& Selwyn, 2020). The opportunities to track children is on the 
increase, including the use of "new, screen-less platforms such as wearables, virtual assistants and connected toys" (Holloway, 2019). This might be an interesting starting point for a critical media education.

\section{Norway - another context - similar trends}

Teaching and learning is not uniform worldwide due to different contexts. The differences between Norway and, for example the USA, are large. In Norway a well funded public school system allows less scope for private schools and organizations. Foundations play a minor role and the headquarters of the technology giants and the large international institutions are at a safe distance, physically at least. Nevertheless, the same kinds of concepts and arguments for introducing new technology have been used to a large extent in Norway. Curricula contain the same vast ambitions of integrating the latest technological solutions. But who are the major actors in Norway? What kind of networks exist? What about the representatives of the large technology companies, their relations to the authorities, politicians, schools, municipalities and research institutions? It is uncontested that large amounts of equipment from the big companies fill the schools, also in Norway, having a significant impact on school development. The two technology giants, Apple and Google, occupy dominant positions and have been greeted with considerable enthusiasm. They have met limited resistance and scepticism. The two companies have in various ways collaborated with and received support from national actors. Based on the analyses, the main actors have been categorized as follows: Norwegian government and the governmental actors who are suppliers of premises and responsible for implementing the government's policy, commercial actors as consultants in educational technology and salesmen of equipment and software, the representatives of the global technology giants, the Norwegian edtech industry, national and international conference organizers, academics and the media.

\section{Intensified digitization processes due to the pandemic}

Teaching in Norwegian schools were digitized at record speed in 2020 as in other countries around the world. It has been commented that changes that could otherwise have taken 10-15 years to develop were now happening in a couple weeks. All students were for a period offered digital education at home. ${ }^{1}$ A common perception was that education probably was changed forever. ${ }^{2}$ Activities in higher education via Zoom, the most used video service, increased from around 150 meetings and somewhere between 500 and 2000 participants daily, to well over 5,00o meetings and 55,000 participants. 3 The Prime

\footnotetext{
${ }^{1} 2020$ https://www.ikt-norge.no/kommentar/ikt-bransien-leverte-som-best-nar-den-trengtes-som-mest/

22020 https://www.forskerforum.no/hva-har-vi-laert/

${ }^{3} 2020$ https://khrono.no/universitetene-og-hogskolene-omstiller-seg-i-rekordfart/473754
} 
Minister could conclude that the pandemic had given Norway a new digital everyday life. 4

On the other hand, compared with the situation described in the first part of the article, there have so far been few signs in Norway that this intensified digitization has led to the introduction of new actors, partnerships, increased privatization and commercialization involving new forms of influence on educational policy. When it comes to privatization and commercialization, it has traditionally been limited due to a well-funded public school. Another reason for quite few changes in Norway in terms of actors and networks during the pandemic may have been the large investment in ICT in schools in the years before 2020. This had brought Norwegian classrooms up among the best in the world when it comes to equipment.

It was not the lack of computers or tablets that was the main problem when the pandemic broke out, but rather how to use them in the best possible way. This is reflected in the action plan for digitization in primary and secondary education 2020-2021 presented by the Ministry of Education during the pandemic. Based on a survey conducted after the schools closed, the main conclusions are that digitization has gained a new meaning, that there is a need for more competence, but that the situation with regard to infrastructure has been perceived as generally good. 5 This is confirmed by representatives of the Norwegian ICT industry. They stated that the reason why Norway managed to move all students to digital education at home so easily was the efforts from the industry in previous years. ${ }^{6}$ However, it should also be mentioned that the intensified digitization processes made people feel worried about the new challenges in society and the school, which they also expressed.7 Furthermore, cyber security and increased risk of digital attacks and online fraud were topics addressed. 8 There were public debates on these topics, and books were published by commentators who thematized the challenges associated with the new "techno powers" (Hareide, 2020) and living in the "time of algorithms" (Stenvik, 2020).

Nevertheless, none of this seems to have made any impact on the dominant Norwegian policy in educational technology. When it comes to the activities of the dominant actors, the relationships between them and the development of the networks over time, there seem to be many similarities with what has been the situation internationally as it is presented in the first part of the article.

\footnotetext{
${ }^{4} 2020$ https://www.regieringen.no/no/aktuelt/korona-pandemien-har-gitt-norge-en-nv-digital-hverdag/id2828489/

52020 https://www.regieringen.no/contentassets/44b8b3234a124bb28f0a5a22e2ac197a/handlingsplan-fordigitalisering-i-grunnopplaringen-2020-2021.pdf

${ }^{6} 2020$ https://www.ikt-norge.no/kommentar/ikt-bransien-leverte-som-best-nar-den-trengtes-som-mest/

${ }^{7}$ 2https://www.forskerforum.no/hva-har-vi-laert/020

${ }^{8} 2020$ https://www.finansnorge.no/aktuelt/nyheter/2020/korona/ikt-sikkerhet-og-okt-risiko-for-digitale-angrep-ogbedrageri-pa-nettet/
} 


\section{Governmental actors and a profound technology optimism}

The Norwegian government and the leading political parties have acted in keeping with the European Union and OECD in terms of the need to implement new technology in education. A profound technology optimism has affected the entire public administration from the government level and to the various municipalities (Haugsbakk, 2011). The action plans have been overburdened with expectations of improved learning and visions of "the digital school". This relates to notions of an "e-Norway" in which the digitally competent "ecitizens" find all they require through fully digitalized, 24-hour available, public services.

The Norwegian Centre for ICT in Education, falling under the authority of the Norwegian Ministry of Education and Research, has been a key actor in this respect. The Center's mission has been to provide the government with the necessary premises in which to make its strategic decisions and to implement government policy within the area. This means the use of ICT for "improving the quality of education and improving learning outcomes and learning". 9 In 2018 the Center was merged with the Directorate for Education and Training, which is the executive agency for the Ministry of Education and Research.

The Center has nurtured a relationship with many of those who have supported the official, politically adopted strategy in the field of educational technology. It has distributed research and development funds, conducted seminars and conferences and have been responsible for important international contacts in the field in relation to the EU. For a number of years the Centre also hosted Nordic@Bett, an official part of the Bett Show in London, together with Nordic partners. To some extent this arrangement can be considered on a par with the presentation of the Norwegian edtech industry at Bett within the pavilion of The Norwegian Classroom. ${ }^{10}$

In 2006 the Centre of ICT in Education also initiated a peer-reviewed open access scholarly journal, the Nordic Journal of Digital Literacy. Analyses of the journal have revealed a clear distinction between the articles and the editorials, the latter of which are clearly linked to the dominant political arguments and the mandate of the Center and based largely on governmental plans, OECD and EU documents. Critical perspectives on the development within the field of educational technology are lacking (Haugsbakk \& Nordkvelle, 2020).

\footnotetext{
9 https://iktsenteret.no/english This website is no longer accessible, but may be accessed on web.archive.org: https://web.archive.org/web/20180116094430/https://iktsenteret.no/english
}

${ }^{10}$ See more about the Bett Show in the following. 


\section{NMC - a partner linked to the global edtech industry}

The partnership between the Centre for ICT in Education and the New Media Consortium (NMC) is interesting since the NMC can be seen as a governmental partner with obvious links to the global edtech industry. ${ }^{11}$ The NMC defined itself as "an international community of experts in educational technology" whose aim was to assist institutions worldwide to "stay at the leading edge of emerging technology". ${ }^{12}$ The organisation was founded in 1993 by a group of hardware manufacturers, software developers and publishers. They realised that "the ultimate success of their multimedia-capable products depended upon their widespread acceptance by the higher education community in a way that had never been achieved before". ${ }^{13}$ Thus the NMC's "raison d'être" has been to "sell us stuff" (Grussendorf, 2018). Adobe, Apple, Hewlett-Packard, Intel. and Pearson have been among its strategic partners.

The Center's partnership with NMC has apparently never been problematized. Moreover, the NMC's most significant contributions, the Horizon Reports predicting future technology trends in educational settings, have become a mainstay resource and have influenced educational technology purchasing decisions (ibid.). Few questions, if any, have been raised about the panel of experts. The panel has been reserved for those who are members of NMC, including several global technology companies and some members from institutions like the Center of ICT in Education. NMC's Delphi method has also avoided critical comments. The method is designed for the building of consensus, a potential challenge taken into consideration the group of technology corporations being their founders and their proclaimed intentions.

The NMC reports have been regarded as neutral reference works in large parts of the world. Such is also the case in Norway. When the Norwegian national broadcasting (NRK) presented the report on Technological Outlook for Norwegian schools 2013-2018, the title was: "Soon ready for the digital school". NRK obtained a statement from the Minister of Education agreeing that the future prospects looked very exciting. The Centre confirmed the report findings stating further that a shift to better and more effective learning would occur once digital tools had been introduced. ${ }^{14}$

A similar presentation of the report was made by the largest online news service covering Norwegian and international research in the Nordic countries, forskning.no, initiated by the Research Council of Norway. 15 Their main angle was that the new technology would

\footnotetext{
${ }_{11}^{11}$ NMC partners: https://web.archive.org/web/20171219142221/https://www.nmc.org/member-type/partners/

12 http://web.archive.org/web/20150908060814/http://www.nmc.org/about/nmc-history/

${ }^{13}$ The same website.

${ }^{14} 2013$ https://www.nrk.no/rogaland/ny-teknologi-i-skolen-1.11362391

${ }^{15} 2011$ https://forskning.no/om-forskningno/about-forskningno/990987
} 
turn the classroom upside down and would pose a major challenge for teachers who taught in the old-fashioned way. The findings were not commented on in any way, and no questions were raised about the research project, the way it had been carried out or the responsible researchers, the "experts" as they were called. ${ }^{16}$

\section{Commercial actors - advisors and salesmen}

Rikt (Resources for ICT) and Atea have been selected as important representatives of commercial actors in the field of educational technology in Norway. Both have been advisors to a number of schools and municipalities as to their strategic choices and the purchase of equipment. At the same time, they have been resellers of equipment from the major technology companies. The technology giants themselves have to varying degrees been visible as actors.

\section{Rikt - Apple's faithful partner}

Rikt has been a very important partner for Norwegian schools and municipalities during the last decade. Many of its activities are relatively well documented through posts on its website and through a number of news articles and press releases in local newspapers. These sources include some transparency regarding business partners, consulting practices, the use of conferences, seminars and various other types of meeting places.

Rikt presents itself as the competence partner that helps kindergartens, primary schools and upper secondary schools to achieve increased learning on digital platforms. Over a 10year period it has grown to about 40 employees and has concluded that it has probably become "Europe's largest competence partner in the field". Rikt has been involved in schools and kindergartens in more than 130 municipalities and county municipalities throughout Norway. ${ }^{17}$ They regard themselves as "a bunch of enthusiasts who are passionate about seeing change in school". ${ }^{18}$ However, they have had a dual function as a competence partner and advisor on the one hand, and as a marketer and reseller of technical equipment on the other. They are authorized resellers of Apple products ${ }^{19}$, and the implementation of iPads in schools has been a "primary target" since $2011 .^{20}$

The marketing aspect seems to have been most evident in the early years of the company's history, but it provides a good illustration of an active salesman. The iPad is marketed quite heavily through their websites using all the well-known slogans. It has been

\footnotetext{
${ }^{16} 2013$ https://forskning.no/data-informasjonsteknologi-skole-og-utdanning/vil-snu-opp-ned-paklasserommet/599050

172021 https://rikt.net/change2020/

182021 https://rikt.net/\#om-oss

${ }^{19} 2021$ https://rikt.net/drift/

${ }^{20}$ https://ischolengroep.org/2012/09/better-learning-the-ultimate-target-for-modern-schools-keynotemacscholendag-door-erling-gronlund/ Keynote MacScholenDag - iScholenGroep - not accessible any longer
} 
described as a "fantastic personal learning tool" 21 causing "increased production, increased motivation, increased learning and increased mastery in the classroom". ${ }^{22}$ It has been referred to as representing "an explosion in learning" and "a new spring". 23 The promise of "increased learning outcome" occurs frequently. Blog posts on their web pages contain several success stories about what is achieved through their efforts to assist schools and municipalities to implement new technology.

Rikt has marketed Apple's conferences ${ }^{24}$ and "Leadership Tours". ${ }^{25}$ Moreover, the company was the first in Norway to gain certification in such courses as "Apple Professional Development". ${ }^{26}$ However, Rikt is also authorized reseller of Showbie ${ }^{27}$ and became 2016 a partner with Interactive Norway importing SMART Board. ${ }^{28}$

Rikt has developed an extensive network containing public institutions, schools, municipalities, business actors, educational researchers and school leaders. Central to this network have been well-established meeting places and conferences. The most significant is the Bett Show in London where Rikt for many years conducted its own sub-conference for customers and other participants recruited from Norway.

In the Norwegian context, the NKUL conference (National Conference on the use of ICT in education and learning) seems to have performed some of the same functions. NKUL is Norway's largest conference for those interested in this field. ${ }^{29}$ It proved to be an important conference for Rikt, both as a meeting place and for presenting their projects and marketing their products and services. Rikt's school leader network has held meetings at the NKUL as well as at Bett. 30

\section{Atea - larger, different and addressing “all” global companies}

Atea presents itself as the market leader in IT infrastructure for businesses and publicsector organizations in Europe's Nordic and Baltic regions with more than 7000 employees located in 84 offices across seven countries. ${ }^{31}$ This is a much larger organization than Rikt and different in structure. Atea offers a wide range of hardware and software, as well as teams of specialists prepared "to design, implement and operate solutions for even the most complex IT requirements". Their technology partners are leading international IT companies, including Microsoft, Cisco, HP Inc., Hewlett Packard, Apple, IBM, Dell EMC,

\footnotetext{
${ }^{21} 2012$ https://rikt.net/ipad-et-personlig-laeringsverktov/

222013 https://rikt.net/motivasion-mestring-og-mve-moro/

${ }^{23} 2014$ https://rikt.net/en-ny-var-pa-saltveit-skole/

${ }^{24} 2011$ https://rikt.net/apple-inviterer-til-konferanse-ipad-i-skolen/

${ }^{25} 2013$ https://rikt.net/apple-leadership-tour-besoker-oslo-12-13-feb/

${ }^{26} 2011$ https://rikt.net/fantastisk-mye-moro-i-aret-som-gikk/

272020 Showbie Resellers https://www.showbie.com/resellers/\#norway

${ }^{28} 2016$ https://rikt.net/rikt-oker-tempoet/

${ }^{29}$ See more about NKUL in the following.

${ }^{30} 2016$ https://rikt.net/skoleledernettverk/

312021 https://www.atea.com/about-atea/
} 
Lenovo and Citrix. Atea was founded in 1968 under the name Merkantildata, as a pioneer within the emerging market for information technology within Norway. ${ }^{2}$

Educational technology is one of five focus areas for Atea. The others are welfare technology, smart building, aquaculture and oil and gas. 33 With respect to educational technology Atea presents itself as a partner for the school's digital journey in the field of strategy development, technology selection and teacher training. Atea will help to identify technical and educational software best suited to the school in question. One of the main reasons why schools opt Atea as a partner, they argue, is that the company is "local and close", and that it employs advisers with a solid school background and competence. 34

Atea is an Apple partner and an Authorized Apple Reseller. Their aim is to take Apple into "the corporate, educational and public markets".35 In 2017 over one million iPads had been delivered by Atea to schools in Scandinavia. Atea has developed their own Apple school team and thousands of teachers have completed courses in the use of iPads in the classroom. ${ }^{36}$ They have organised projects in several Norwegian schools and municipalities thereby contributing to the development of visions and strategies while also reselling several thousands iPads, licenses and other accessories. 37

Atea has also entered into contracts with municipalities given their partnership with leading companies in personal computers. ${ }^{38}$ They have been serving the largest urban municipalities in Norway, Oslo, Bergen and Trondheim, covering many of their administrative needs. In 2018 they signed a contract with the Trondheim municipality potentially worth around NOK 400 million. The contract included the responsibility for about 34,000 of the municipality's PCs, mobile phones and tablets. An important part of this was providing Google's Chromebooks for all schools. ${ }^{39}$ Atea's commitment to the education sector includes monitoring Google's products and services as well as conducting courses based on Google G Suite for Education. ${ }^{40}$

Atea has been conducting school projects in programming and algorithmic thinking. ${ }^{41}$

\footnotetext{
322021 https://www.atea.com/about-atea/history/

332021 https://www.atea.no/

342021 https://www.atea.no/skole/

352021 https://www.atea.no/partnere/

${ }^{36} 2017$ https://www.atea.no/fokus/2017/apple-i-skolen/mer-om-atea-og-skole/ (not accessible any more)

37 2018: Rana municipality: https://www.ranablad.no/rana/skole/kultur/kommunen-inngar-leasingavtale-for-3-600nettbrett-avtalen-er-verdt-10-millioner-kroner-over-tre-ar/s/5-42-385101 2020: Furuset Primary school: https://www.atea.no/kundereferanser/furuset-skole/

38 2016: Upper secondary Hedmark. https://www.hamar-dagblad.no/hamar/skole/okonomi-og-naringsliv/loverrobuste-skole-pcer/s/5-80-27512

39 2018: Trondheim https://www.adressa.no/pluss/okonomi/2018/02/02/Sikret-IT-kontrakt-potensielt-verdt-rundt400-millioner-16010533.ece?rs3578801613556432243\&t=1

40 2019: Stavanger https://www.minskole.no/DynamicContent//Documents/38-madlamark-Handlingsplan-for-IKT-istavangerskolen--ccc027b3-4c5e.pdf 2020: Showbie and Socrative and integration with Google for Education https://www.showbie.com/showbie-og-socrative-webinar-for-norske-laerere-og-skoleledere/

${ }^{41} 2020$ https://www.atea.no/siste-nytt/hvordan-ruster-vi-barna-for-livets-mysterier
} 
They have also been responsible for training teachers in coding. $4^{2}$ They have offered different kinds of school leader seminars, including Atea School leadership seminar in connection with Bett. 43 The Bett Show has been an important part of Atea's activities, and with respect to the 2017 Show they were able to proudly announce that they were part of the Apple Solution Expert Village for the second time. 44 They have also been given high priority to the NKUL conference.

\section{The technology giants - increasingly more Google}

Many Norwegians have become addicted to Google's services on a daily basis and regard this as a positive contribution to dealing with challenges in their lives. While accusations of extensive surveillance and the misuse of data have had some impact, these do not appear to have significantly weakened the company's position or the support among leading politicians and the general public. Google has experienced strong growth in the education market both globally and in Norway. Together with Microsoft, Apple for some years enjoyed a solid position in schools in Norway. The presentation of Rikt above illustrates Apple's success based on iPads, but Google has gradually taken the lead. The cost of their machines is low and the software is either free or affordable. The Google Classroom was introduced in Norway in 2014 with the aim of replacing existing learning platforms. Another objective was to introduce students to the Google universe and to sell their own laptops, the Chromebooks (Haugen, 2014).

Google also appears to have practised another approach than Apple in relation to their customers and business partners. An important part of this is having their own country director Norway as in other countries. A high profile leader has given several portrait interviews in Norwegian newspapers and taken part in debates on technology and social development. 45 Google has assumed responsibility for a more comprehensive chain of services for schools and municipalities than is the case with Apple, and the contact they have established with their customers is more direct and takes place to a lesser extent via partners. Google Norway has visited schools, ${ }^{46}$ hosted school visits 47 and introduced innovation camps for students. ${ }^{48}$

Great interest was shown in Google's Chromebooks ahead of the time they were launched in Norway in 2014, but also in the following years. ${ }^{49}$ School leaders throughout the

\footnotetext{
42 2020: Larvik https://www.larvik.kommune.no/skole-og-utdanning/aktuelt/naa-har-vi-egne-kodepedagoger/

${ }^{43} 2019$ https://www.atea.no/arrangementer/2019/ateas-skolelederkonferanse-i-london/atea-skole-lederseminar/ (not accessible any longer)

${ }^{44} 2017$ https://www.atea.no/siste-nytt/trender-fra-bett-show-2017/

452015 https://regenerativemonks.com/2015/11/15/den-norske-google-sjefen-om-fremtiden/

46 2016: Larvik https://www.larvikt.no/google-besoker-larvik/ and December 5, 2019 Bogstad https://bogstad.osloskolen.no/nyhetsarkiv/google-besok/

${ }^{47}$ https://www.itera.no/no/nyhetsrom/blogg/2018/sommerstudenter-hos-google/

48 2019: Rjukan upper secondary school https://www.rablad.no/innovasionscamp-pa-riukanhuset/s/5-90-72047

${ }^{49} 2014$ https://www.tu.no/artikler/stor-interesse-for-chromebook/225550
} 
country, including in Norway's second and third largest cities, Bergen and Trondheim, decided to go for Google Classroom together with Google's Chromebooks, Trondheim in $2016^{5}$ and Bergen in 2019. ${ }^{11}$ Parents and commentators have expressed concern about the risk posed by Google's practice of abusing private information, and the Norwegian Data Protection Authority as early as in 2012 as the country's first municipality switched to Google's e-mail system for all employees..$^{2}$ As a consequence, the Center for ICT in Education on behalf of the Ministry produced a guide for municipalities and schools. Rather than putting forward criticism of the companies, the guide included advice to the municipalities to read the terms carefully and ask the right questions. 53

The behaviour of the global technology giants has received limited critical comments by Norwegian researchers. Moreover, it is the positive and enthusiastic comments that have been more visible. Such observations include the reluctance to demonise Google for acting in an open market along with others. Google, Facebook, Microsoft and Apple are integrated parts of our daily lives, whether we like it or not.54 For a number of years a prominent academic published rather favourable comments about several aspects of Google's activities. This included how he had incorporated Google for teaching purposes. 55 Further, he argued that the positive effects of obtaining the data offered by Google significantly outweighed for most people any possible threats ${ }^{6}$ and that Google was unlikely to abuse its position given that it depends on the customer's trust.57

The Government and the leading political parties have up til now largely regarded Google's activities as very positive. Much attention has been given to the company's plans to establish huge data centres in Norway. Indeed, in 2019, the Minister of Digitization described the purchase of an extensive area near to a Norwegian city, as very good news, and the mayor claimed that there would be celebrations. ${ }^{8}$ Similar plans elsewhere in Norway have been met with the same kind of enthusiasm.

\section{The Bett Show - where all meet}

Bett has been the most important event for several of the key actors in Norway, as mentioned above. The Bett Show (formerly known as the British Educational Training and

\footnotetext{
50 2021: Trondheim https://www.trondheim.kommune.no/skole/ikt/

51 2021: Bergen https://www.bergen.kommune.no/innbvggerhielpen/skole/grunnskole/grunnskoleopplaring/digitaleverktov-i-skolen

522012 https://www.d Bogstad igi.no/artikler/derfor-ble-det-nei-til-google/198431

532012 https://www.digi.no/artikler/skvinteressen-enorm-i-norsk-skole/293865

${ }^{54} 2016$ https://www.utdanningsnytt.no/digital-kompetanse-skole-teknologi/google-skolen-digitale-gratislosningertar-over-i-skolene/167955

552015 https://www.krokan.com/arne/2015/01/16/google-pavirker-maten-vi-tenker-pa/

${ }^{56} 2014$ https://www.krokan.com/arne/2014/11/26/hva-har-ladygaga-og-google-til-felles/

572014 https://www.krokan.com/arne/2014/11/14/vil-du-vite-mer-om-google/

582019 https://www.aftenposten.no/norge/i/naBdAm/google-har-kjoept-giganttomt-i-skien
} 
Technology Show) is a global series of education shows with its main site being in London. The first Bett Show was held in that city in 1985 and has since become an annual four-day event that attracts some 700-800 exhibitors and around 35,000 participants. Bett's own understanding is that it "celebrates education and inspires future discussions as together we discover how technology and innovation enable educators and learners to thrive".59

However, David Buckingham has described The Bett Show as "a prime example of what might be called the educational-technological complex in action" as it represents "a powerful alliance between public and private interest" including marketers, commercial actors, government departments, educationalists, researchers and journalists (Buckingham, 2007, p. 12). Bett has also been criticised for marginalising teachers due to its increasingly commercial nature (Davitt, 2008), and trade shows like Bett are regarded as problematic because "teacher agency is shaped and controlled by the discursive, material and affective dimensions of such events" (Player-Koro, Rensfeldt \& Selwyn, 2018, p. 700).

For several years the Centre for ICT in Education hosted Nordic@Bett as an official part of the Bett Show in London. Bett has also been the site of joint efforts on the part of the Norwegian edtech industry to present itself within its own pavilion, "The Norwegian Classroom", coordinated by ICT Norway. Rikt has hosted sub-conferences in London for its participants recruited from Norway, and some of Atea's school leadership seminars are held in London and include visits to Bett.

The significance of Bett from the Norwegian perspective is made quite clear by the fact that the Crown Prince of Norway performed the official opening of The Norwegian Classroom in 2017. ${ }^{\circ}$ Some of the most prestigious Norwegian projects and actors have been presented at Nordic@Bett, for instance The Horizon Report 2015 including the technology outlook for Scandinavian schools.

\section{NKUL - Norway's key meeting place for the use of edtech}

NKUL (The National Conference on the use of ICT in education and learning) is Norway's largest meeting place of the sort. The main organizer responsible is NTNU, Norwegian University of Science and Technology, with a main profile in science and technology. ${ }^{61}$ The target group for the conference is teachers, school leaders, teacher educators and participants from the education sector in general. ${ }^{62}$ NKUL has been held every year since

\footnotetext{
592021 https://www. bettshow.com/about-bett

602017 http://osloedtech.no/2017/01/the-norwegian-classroom-bett-2017/

${ }^{61} 2021$ https://www.ntnu.edu/about

622021 https://www.nkul.no/om-nkul/
} 
$1995 \cdot 63$

In the Norwegian context, the NKUL conference seems to have attracted almost the same kinds of participants from Norway as Bett. The key actors present their plans, projects, experiences, products and services, and the conference plays an important role as a meeting place.

A sizeable group of co-organizers and partners contribute professionally and financially to the conference. The Norwegian Directorate for Education and Training is an important coorganiszer, and among the partners is also Utdanningsforbundet, a Norwegian trade union for educators. Other partners are publishing houses as well as a number of software and hardware developers as Epson, Google, Itslearning, LearnLab, Microsoft and Visma. ${ }^{64}$

The Norwegian Centre for ICT in Education has presented their Innovation Awards at NKUL as they have done at Bett, ${ }^{6}$ likewise the Horizon Reports developed by the Center and NMC. ${ }^{66}$ Both Rikt and Atea have actively recruited participants for the conference.

\section{ICT Norway and the Norwegian edtech industry}

ICT Norway is an important actor in the field of educational technology since it represents the interest group for the Norwegian ICT industry. Their main ambitions are to enlarge the market, remove obstacles to their members, increase value for the industry and provide assistance with internationalization and capitalization. ${ }^{67}$

Since the the main focus of the article is on the global technology giants, the Norwegian technology actors may appear to be small and insignificant. They do not have the same kind of influence, but they are nevertheless important for the development of the dominant attitudes towards technology in Norwegian society. ICT Norway seems to have enjoyed a fruitful relationship with the government and the leading political parties, as well as with the other key actors in educational technology. One of the chief reasons is probably that they have supported many of the basic views on ICT development in society. They have arranged joint seminars with the Conservatives, currently the leading government party in Norway, about ICT in education. ${ }^{68}$ However, in this respect, the Conservatives and the Labour Party agree on the main issues while representatives of these parties endorse full support to ICT Norway's view that the Norwegian edtech companies must have improved conditions and easier access to Norwegian schools. ${ }^{69}$

\footnotetext{
632021 https://www.nkul.no/historikk/

${ }^{64} 2021$ https://www.nkul.no/samarbeidspartnere/

652015 https://rikt.net/innovasionsprisen-2016-til-iong-skole/

${ }^{66} 2013$ https://rikt.net/hvorfor-byod-neppe-er-bra-for-skolene/

672021 https://www.ikt-norge.no/english/

682012 https://www.ikt-norge.no/nyheter/miniseminar-ikt-og-utdanning/

${ }^{69} 2015$ https://www.utdanningsnytt.no/pedagogikk-skoleutvikling/iakten-pa-framtidseleven/168391
} 
By representing developers and sellers of new technology, ICT Norway wants teachers and schools to become more active users. They emphasize that Norwegian edtech companies have over 300 million users, but too few among Norwegian teachers. ${ }^{70}$ ICT Norway underlines that edtech has become a mature industry - one based as much on pedagogy as on technology.

A good indication that ICT Norway works well with the other key actors in Norway is their contribution to the Bett Show. Nordic@ Bett hosted by the Center of ICT in Education and The Norwegian Classroom by ICT Norway have been regarded as two almost parallel ways of representing Norway abroad.

The Norwegian edtech industry is not devoid of great success stories, but they might also serve to illustrate the influence of big global business. The pioneers and the largest Norwegian edtech companies, the learning platforms Fronter and Itslearning, were founded in 1998 and 1999. Following prolonged success, Fronter was sold to the international giant Pearson in 2008, but was then acquired by Itslearning in 2015. In 2018 Itslearning and Google announced that they had agreed to collaborate. ${ }^{71}$ This probably came as a surprise to a lot of people as the director of Itslearning had one year before warned against letting Google into Norwegian schools. He believed children's privacy could be harmed. ${ }^{22}$ This may be an indication of how business is being done in this field. The arguments become more parts of a business oriented tactical play than enlightening for ordinary users.

\section{Discussion and concluding remarks}

The article has looked at the international debates on the influence of the technology giants on educational policy. The company's objectives include the development of new long-term policy agendas. In part this can be seen as a prolongation of developments from the $1990 \mathrm{~s}$ onwards, but has been significantly intensified and has to some extent changed character since the onset of the pandemic. This has given rise to new multisector coalitions and increasingly complex networks where the large international organisations and technology giants are partners. The pedagogical implications might be profound, but require further examination. As outlined in the introduction of the article, the project presented is just a first step trying to identify and analyse the roles of the main actors in the field. A lot more systematic work is needed. It is challenging to give a comprehensive picture of the different approaches that the various companies have followed and the networks they have established. Together these conditions constitute important limitations of the project so

\footnotetext{
702019 https://www.aftenposten.no/norge/i/zGQAvO/norske-edtech-selskaper-har-over-300-millioner-brukere-mennorske-l

712018 https://itslearning.com/en/news/itslearning-og-google/

722017 https://arkiv.klassekampen.no/article/20170419/ARTICLE/170419980
} 
far.

However, the preliminary mapping of actors and channels of influence in a Norwegian context reveals that there are many similarities in the field of educational technology, despite differences between countries, their political and educational systems, traditions and values. These similarities include how the use of new technology is valued as a way of improving teaching and learning. It is not possible to gain accurate insight into what is being done and on what grounds, how the various actors relate to each other, what influence they have, and what this ultimately means for the development of education policy. On the other hand, based on the analysis some patterns seem to emerge.

This includes how teaching in schools was digitized at a record speed in 2020. However, to a smaller extent than in some other countries in Norway this does not seem to have led to obvious changes regarding partnerships and networks in the field of educational technology and their ability to influence educational policy. One part of the explanation might be that a well-funded public school has left less room for privatization and commercialization. Another part might be that the large investment in ICT in schools the years before the pandemic had brought Norwegian classrooms up among the most wellequipment in the world. This might also have limited the possibilities for new initiatives during the pandemic.

Nevertheless, it is the similarities that are most striking when it comes to defining the trends in the Norwegian material, and these can be understood largely as extensions of developments that have taking place since the 1990s. One major trend seems to be an acceptance of key commercial actors in the field of educational technology combining the roles of advisors and salesmen. An interesting question is to what extent this may be related to the fact that technology is largely perceived as a neutral field independent of values, ideology and political perspectives.

Another important trend is that there are close links between education and the edtech industry. This can be seen as an extension of the preceding point. Another instance of this trend is for instance the partnership between The Center for ICT in Education and The New Media Consortium that might be regarded as a direct link between government and industry. There is also a close link between the government and ICT Norway representing the Norwegian edtech industry. Although meeting places for the edtech industry and the government in the field of education are valuable, it is challenging if they are not combined with a certain distance and critical reflection. Finally, it appears that also in Norway there is a common pro-technology agenda that unites government actors, various commercial actors, industry, some of the major conference organizers, the most visible academics and the media. As the analyzed material from the Norwegian context illustrates, the main actors are connected in different ways and have got meeting places and networks of various kinds to develop and shape their agendas. The role of the media has not been discussed in 
detail in the article, but more indirectly in the way news in the edtech field has been communicated.

Overall, the analyses based on the Norwegian context reveal a type of network rather close to the ones Picciano (1994) described emerging in the early 1990s. They included near relations between business, politics and a large and growing number of actors with common interests related to technology in education. The networks have been based on perceptions of educational technology presented as true and self-evident, and they can be seen as parts of hegemonic meaning constructions to a small extent opening up for alternative perspectives (Laclau \& Mouffe, 2001).

Gradually, more critical questions have been raised about what is going on in education technology and why, but there is a need for more systematic approaches that go into the whole range of interesting questions related to the technology giants and their influence on education policy. Doubt and uncertainty must be made parts of these reflections. Furthermore, it is important to direct the conversations towards "education as a social concern", not a "tech issue" (Selwyn, 2020) and to lay the foundation for a new critical media education.

\section{References}

Adams Becker, S.; Cummins, M.; Freeman, A. \& Rose, K. (2017). 2017 NMC Technology Outlook for Nordic Schools: A Horizon Project Regional Report. Austin, Texas: The New Media Consortium.

Andriole, S. (2018). Big Trouble for Facebook, Amazon, Google And Apple in 2018. Forbes. January 3. https://www.forbes.com/sites/steveandriole/2018/01/03/big-troublefor-facebook-amazon-google-apple-in-2018/\# eac61f64d87d

Ball, S. J. \& Junemann, C. (2012). Networks, new governance and education. Bristol: Policy Press.

Biesta, G. (2004). Against learning. Reclaiming a language for education in an age of learning. Nordisk Pedagogikk, 24 (1), 70-82.

Colclough, C. J. (2020). Teaching with Tech. The role of education unions in shaping the future. Report of a survey conducted by Education International July - September 2020. Education International.

https://issuu.com/educationinternational/docs/2020 ei research teachingwithtec $\underline{h}$ eng?fr=sMjE3NTIzMTk5MTA

Davitt, J (2008). Are teachers getting a fair deal? The Guardian. March 18.

Global Finance (2020). World's Largest Companies 2019. https://www.gfmag.com/globaldata/economic-data/largest-companies 
Grussendorf, S. (2018). A critical assessment of the NMC Horizon reports project.

Compass: Journal of Learning and Teaching, 11(1).

https://doi.org/10.21100/compass.v11i1.722

Hareide, D. (2020). Mennesket og teknomaktene. Oslo: Aschehoug.

Haugsbakk, G. (2011). How Political Ambitions Replace Teacher Involvement: Some

Critical Perspectives on the Introduction of ICT in Norwegian Schools. Nordic

Journal of Digital Literacy, 6(4). https://doi.org/10.18261/ISSN1891-943X-2011-

$\underline{04-04}$

Haugsbakk, G. \& Nordkvelle, Y. T. (2020). On the expression of hegemony in the field of educational technology - a case study of editorials in a Norwegian academic journal. Seminar.net, 16(2). https://doi.org/10.7577/seminar.4044

Hogan, A. (2015a). How big business is taking over public schools: is this what we want for Australia? EduResearch Matters. https://www.aare.edu.au/blog/

Hogan, A. (2015b). Boundary spanners, network capital and the rise of edu-businesses: the case of News Corporation and its emerging education agenda. Critical Studies in Education, 56(3). https://doi.org/10.1080/17508487.2014.966126

Hogan, A.; Sellar, S. \& Lingard, B. (2016a). Commercialising comparison: Pearson puts the TLC in soft capitalism. Journal of Education Policy, 31(3), 243-258 http://dx.doi.org/10.1080/02680939.2015.1112922

Hogan, A.; Sellar, S. \& Lingard, B. (2016b). Corporate social responsibility and neo-social accountability in education. The case of Pearson plc. In: A. Verger; C. Lubienski \& G. Steina-Khamsi (Eds.), World Yearbook of Education 2016. The Global Education Industry.

Holloway, D. (2019). Surveillance capitalism and children's data: the Internet of toys and things for children. Media International Australia, 170(1), 27-36. https://doi.org/10.1177/1329878X19828205

Johnson, L.; Adams Becker; S., Ludgate, H.; Cummins, M. \& Estrada, V. (2012). Technology Outlook for Singaporean K-12 Education 2012-2017: An NMC Horizon Project Regional Analysis. Austin, Texas: The New Media Consortium. http://www.nmc.org/pdf/2012-technology-outlook-for-singapore-k12-education.pdf

Johnson, L.; Adams Becker, S.; Cummins, M. \& Estrada, V. (2013). Technology Outlook for Norwegian Schools 2013-2018: An NMC Horizon Project Regional Analysis. Austin, Texas: The New Media Consortium.

Johnson, L.; Adams Becker, S. \& Hall, C. (2015). 2015 NMC Technology Outlook for Scandinavian Schools: A Horizon Project Regional Report. Austin, Texas: The New Media Consortium. 
Klein, N. (2020). How big tech plans to profit from the pandemic. The Guardian, May 13 2020. https://www.theguardian.com/news/2020/mav/13/naomi-klein-how-bigtech-plans-to-profit-from-coronavirus-pandemic

Knox, J.; Williamson, B. \& Bayne, S. (2020) Machine behaviourism: future visions of 'learnification' and 'datafication' across humans and digital technologies. Learning, Media and Technology, 45(1), 31-45, https://doi.org/10.1080/17439884.2019.1623251

Koselleck, R. (2004). Futures past. On the semantics of historical time. New York: Columbia University Press.

Laclau, E. \& Mouffe, C. (2001). Hegemony \& socialist strategy. Towards a radical democratic politics. London: Verso.

Pangrazio, L. \& Selwyn, N. (2020). Towards a school-based 'critical data education'. Pedagogy, Culture \& Society. https://doi.org/10.1080/14681366.2020.1747527

Perrotta, C. (2020). Programming the platform university: Learning analytics and predictive infrastructures in higher education. Research in Education. https://doi.org/10.1177/0034523720965623

Perrotta, C.; Gulson, K. N.; Williamson, B. \& Witzenberger, K. (2021). Automation, APIs and the distributed labour of platform pedagogies in Google Classroom. Critical Studies in Education, 62(1), 97-113. https://doi.org/10.1080/17508487.2020.1855597

Picciano, A.G. (1994). Technology and the Evolving Educational-Industrial Complex. Computers in the Schools, 11(2). https://doi.org/10.1300/Jo25v11no2 08

Picciano, A.G. \& Spring, J.H. (2013). The great American education-industrial complex. Ideology, technology, and profit. Routledge. https://doi.org/10.4324/9780203120613

Player-Koro, C; Rensfeldt, A. B. \& Selwyn, N. (2018) Selling tech to teachers: education trade shows as policy events, Journal of Education Policy, 33(5), 682-703. https://doi.org/10.1080/02680939.2018.1476735

Regan, P. M. \& Khwaja, E. T. (2019). Mapping the political economy of education technology: A network perspective. Policy Futures in Education, 17(8), 1000-1023. https://doi.org/10.1177/1478210318819495

Schiller, D. (1999). Digital Capitalism. Networking the Global Market System. MIT Press. https://doi.org/10.7551/mitpress/2415.001.0001

Selwyn, N. (2011). Schools and schooling the digital age. London: Routledge. 
Technology giants, educational policy and a preliminary mapping of networks and channels of influence

Selwyn, N. (2020). Digital education in the aftermath of COVID-19: critical concerns \& hopes. Techlash, 1. https://der.monash.edu.au/lnm/wpcontent/uploads/2020/06/TECHLASH-01-COVID-education.pdf

Stenvik, B. (2020). Det store spillet. Hvordan overleve i algoritmenes tidsalder. Oslo: Cappelen Damm.

UNESCO (2020). UNESCO rallies international organizations, civil society and private sector partners in a broad Coalition to ensure \#LearningNeverStops. Press release March 26. https://en.unesco.org/news/unesco-rallies-international-organizationscivil-society-and-private-sector-partners-broad

UNICEF (2020). UNICEF and Microsoft Corp. today announced the expansion of a global learning platform to help children and youth affected by COVID-19 continue their education at home. Press release April 20. https://www.unicef.org/pressreleases/unicef-and-microsoft-launch-global-learning-platform-help-address-covid19-education

Verger, A.; Lubienski, C. \& Steiner-Khamsi, G. (2016). The Emergence and Structuring of the Global Education Industry. Towards an Analytical Framework. In: A. Verger, C. Lubienski \& G. Steina-Khamsi (Eds.), World Yearbook of Education 2016. The Global Education Industry. Routledge.

Walsh, J. D. (2020). The Coming Disruption. Scott Galloway predicts a handful of elite cyborg universities will soon monopolize higher education. Intelligencer - New York Magazine, May 11, 2020. https://nymag.com/intelligencer/2020/05/scott-gallowayfuture-of-college.html

Wetherell, M.; Taylor, S. \& Yates, S. J. (2001). Introduction. In M. Wetherell, S. Taylor, \& S. J. Yates (Eds), Discourse theory and practice. A reader, (1-8). London: Sage.

Williamson, B. (2016). Political computational thinking: policy networks, digital governance and 'learning to code'. Critical Policy Studies, 10(1), 39-58. http://dx.doi.org/10.1080/19460171.2015.1052003

Williamson, B. (2020). New pandemic edtech power networks. code acts in education, April 1, 2020. https://codeactsineducation.wordpress.com/2020/04/01/newpandemic-edtech-power-networks/

Williamson, B. \& Hogan, A. (2020). Commercialisation and Privatisation in/of education in the context of Covid-19. Brussels: Education International.

https://issuu.com/educationinternational/docs/2020 eiresearch gr commercialisa tion privatisation

Zuboff, S. (2019). The age of surveillance capitalism. The fight for the future at the new frontier of power. Profile Books. 